\title{
Unilever's contribution to achieving sustainable development goals 3 in Indonesia
}

\author{
Dinda Khoirun $\mathrm{Nisa}^{1}$, Arie Kusuma Paksi ${ }^{1 *}$, Amalia Nurul Hutami ${ }^{2}$, and Qholiva Yuni \\ Fadilla $^{3}$ \\ ${ }^{1}$ International Relations Department, Universitas Muhammadiyah Yogyakarta, Indonesia \\ ${ }^{2}$ International Relations Department, Universitas Gadjah Mada, Indonesia, Indonesia \\ ${ }^{3}$ Media and Cultural Studies, Universitas Gadjah Mada, Indonesia, Indonesia
}

\begin{abstract}
This study aims to discuss how Unilever contributes to the achieving of Sustainable Development Goals (SDGs) in Indonesia specifically the third goal that constitutes good health and well-being. This research employs the concept of Corporate Social Responsibility (CSR) to describe how corporations take responsibilities over the community and the environment referring to the ethical theory in implementing the CSR. This research shows the stances and efforts of the company in helping to achieve the Sustainable Development Goals in Indonesia so that a sustainable Indonesian society can be realized by implementing corporate social responsibility to society and the environment.
\end{abstract}

\section{Introduction}

Indonesia is a destination country for multinational companies to become investment targets. Multinational companies are commonly referred to as Multinational Corporations (MNCs). Multinational companies generally have their headquarters in the country of origin of the company and then the multinational company establishes branches in other countries by building or buying assets from other companies in the destination country [1]. The company has full or partial rights to the branch of the company [2]. One example of a multinational company is Unilever.

The year 1933 was the beginning of the founding of Unilever, on December 5, 1933 to be exact. Currently Unilever has grown to become one of the leading FMCG companies in Indonesia. Fast Moving Consumer Goods (FMCG) are products that have a fast turnover, and relatively low costs. FMCG products have a relatively short shelf life due to their perishable nature. The FMCG product category generally includes a wide variety of frequently purchased consumer products. Unilever has become a friend to the people of Indonesia with a variety of products owned by Unilever such as Lifebuoy, Rexona, Vaseline, Sunlight, Pepsodent, Bango, Wall's and many more products from Unilever [3].

Data from the Worldpanel Indonesia office shows an increase in sales of FMCG products from 2012 to 2013 by 14\% throughout Indonesia, both in urban areas and in rural areas [4].

\footnotetext{
*Corresponding author: ariekusumapaksi@umy.ac.id
} 
Unilever's products are not ordinary products, but they have a strong noble purpose. With Unilever's scale and strong noble cause, since 2010 Unilever has succeeded in helping to improve the hygiene and health of approximately 1.3 billion people globally. In addition, Unilever also always strives to campaign for a sustainable lifestyle that is environmentally friendly, healthy and clean, and provides benefits for all [5].

With the Unilever company in Indonesia, it should make Indonesia a more prosperous country and can also help Indonesia in achieving the Sustainable Development Goals (SDGs) by the United Nations. The Sustainable Development Goals have 17 where these goals are useful for achieving sustainable development targets, especially related to health problems. The Sustainable Development Goals apply to all countries (universal), so that all countries without exception have a moral obligation to achieve the goals that are the targets of the SDGs.

Based on the arguments presented above, this study aims to examine how the Unilever company, as one of the MNCs belonging to the FMCG company category, contributes to the achievement of SDGs in Indonesia, especially regarding target number 3 (three) which focuses on good health and well-being. The focus of the analysis is to explain what programs are carried out by Unilever companies and how they are achieved.

\section{Literature Review and Framework}

All companies including multinational companies must have a responsibility to the environment in which the company is located. Multinational companies or multinational corporations, hereinafter referred to as MNCs, are the main actors in international business. Multinational corporations or multinational companies can be defined as companies engaged in direct investment, namely in foreign direct investment (FDI) within certain limits, and controlling the added value of activities in a country [6]. The company must carry out its social responsibility as a form and reflection of a good company. This social responsibility or Corporate Social Responsibility (CSR) is an aspect that cannot be separated from all companies [7]. Both domestic companies and multinational companies. Currently, a company is assessed and considered not only to carry out economic activities and how much profit is obtained in the continuity of its business, but also from how the company carries out its responsibilities towards social aspects and the surrounding environment.

There are many reasons and demands that underlie the application of Corporate Social Responsibility activities. As explained by Frynas that in carrying out Corporate Social Responsibility activities the company has certain considerations and reasons as follows [8]:

1) As a fulfillment of laws, rules, and regulations

2) As a form of social investment for companies to get a good image among consumers and company partners

3) Part of the company's business strategy

4) To obtain an operating permit from the local community

5) Part of the company's risk management to reduce and avoid social conflicts [9].

The Prince of Wales International Business Forum suggests five pillars of Corporate Social Responsibility (CSR) activities, namely [10]:

1) Building Human Capital: Companies are required to form capable human resources and also empower the surrounding community.

2) Strengthening Economies: Companies are not allowed to enrich the company itself, but must also empower the economy of local residents. 
3) Assessing Social Chesion: In order not to cause conflict, the company must establish a good relationship with the surrounding environment.

4) Encouraging Good Governence: companies must conduct business according to good corporate governance

5) Protecting Environment: the company must preserve the surrounding environment.

The implementation of CSR in a company is based on the theory put forward in 2004 by Mele and Geriga and Carroll in 1991. The theory states that the company as part of the community is responsible for achieving economic aspects and is also responsible for the condition of the surrounding community. Morally speaking, the company is responsible for employees, the environment, and other stakeholders involved, as their activities may be potential to endanger as well as pose challenges to the dimension of human security that is related to the environment and economy [11].

In addition, the company is also ethically responsible for employees, the environment, and other stakeholders involved. In the CSR concept proposed by Mele and Gariga, they have 4 theoretical domains in CSR, namely:

1) Instrumental Theory

Instrumental theory is a theory which states that companies carry out CSR with the aim of achieving profit in their economic business to enrich the company. Friedman also believes that to maximize shareholder profits the company is to carry out business responsibilities that are within the legal and ethical framework. In this instrumental theory, companies carry out social activities to achieve their economic goals, which they believe that social activities are a marketing tool.

2) Political Theory

Political theory states that the social power possessed by a company gives rise to corporate social responsibility. Here the company realizes and understands its role as part of the community so that the company must be involved in the community.

3) Integrative Theory

Integrative theory states that companies seek to balance the interests of stakeholders as well as companies with appropriate responses to social issues. Companies use the law as well as public policy processes for reference in social performance. This theory also aims to create social satisfaction.

4) Ethical Theory

This ethical theory focuses on what is right to achieve a better society based on the company's responsibility to the parties involved. This ethical theory highly respects human rights, the environment and the rights of employees. This ethical theory aims to achieve sustainable development by paying attention to current and future generations [12].

From the four theories above, to analyze Unilever Indonesia's contribution to achieving the SDG 3 target, ethical theory will be used. The theory of ethics in business implementation is a theory based on the same ethics that prioritizes the responsibilities of business people. Ethics are values and norms that are used as guidelines in living life. In addition, ethics can help humans to act in accordance with rational actions that can be justified [13]. There are various ethics that must be applied in managing and running a business. With good business ethics, of course, business development will be easier because a good image grows along with business based on ethics. 
The theory of ethics is the parent of social responsibility or CSR. Where a group of people or even on the scale of a company that runs a business has the responsibility to fulfill their duties as citizens. In running a business, it must be profitable for all parties, including the company, society and the environment. Balance in business is very important, because if the balance has been achieved then the responsibility can be declared successful. That's where the role of ethics in business is needed. Every action and decision must be in accordance with its own code of ethics before it is implemented. If an action or decision in doing business causes harm to the community or the surrounding environment, then the company and or business actor is not socially responsible. Social responsibility or CSR has a strong synergy with ethics in business. Both are a unity that has continuity and has an influence on all parties. When ethics and other positive things are applied in business, of course, it will also have a positive impact on business productivity and the rights of employees, the community, and the surrounding environment.

After the explanation above, it can be seen that there are four theories that can be used in analyzing CSR activities, but in this study, specifically to examine Unilever's activities in achieving SDG 3 targets in Indonesia, the author will use ethical theory which explains that CRS activities are part of from activities based on the company's contribution and responsibility in maintaining and contributing to sustainable development, especially in the health sector.

\section{Research Method}

The author in conducting this research uses qualitative research methods, where qualitative research requires several theories in understanding the case studies raised. In collecting data the authors collect data indirectly. Indirect data collection in question, namely the author uses sources from the library both printed and electronic.

\section{Result and Discussion}

\subsection{The Government's Role in the Implementation of CSR Programs}

The government is one of the stakeholders in the implementation of CSR programs. The government has the legitimacy to influence the CSR program so that the CSR program runs in tune with the program run by the government. Currently, CSR has become a priority issue on the government's agenda. The existence of the CSR issue has changed the government's capacity to act and has an impact on social and environmental issues in relation to companies and has also influenced the framework within which CSR policies are designed where the government uses a strategy as all stakeholders. The government must be aware that they bear the mandate and responsibility to ensure the sustainability of environment which can effectively be realized by mainstreaming the sustainable development strategy in all sectors [14]. In designing policies, the government needs to take definite stance putting social and humankind first rather than focusing to expand economic strategy behind the social policies under the framework of environmental preservation and sustainability [15].

There are several things that have been stated by Steurer regarding the reasons for the government's interest in CSR programs [16]. The first reason is because CSR has the same direction as government programs, which is the sustainable development programs where this reason is also related to foreign policy regarding human resource development programs. The second reason is that CSR is a very interesting policy and is considered a complement to existing regulations. For example in Indonesia contained in the Limited 
Liability Company Law where in the law the government is very enthusiastic about showing its concern for social and environmental issues even though the regulations regarding social responsibility or CSR in the law only get very little part. And the third is that the implementation of CSR is still based on the voluntary principle, so only companies that want to do it run the CSR program. This certainly adds to the government's task to place more emphasis on companies to pay more attention and focus on carrying out CSR programs. The fourth reason is that in carrying out CSR, many companies use a partnership program approach or partnership program in which the partnership program invites the community to take part in carrying out CSR, especially in achieving a sustainable society. This involves all the main aspects of CSR, namely the involvement of business stakeholders, the community, and also the government.

In addition to steurers, the World Bank also has five categories regarding the role of the government in supporting the implementation of CSR programs. In the public sector, the government has four roles, namely the mandatory role or the role of legislation, the role of endorsement, the role of partnering, and the role of facilitating [17].

The four categories of roles are described in detail by O'Rouke. The first role is the mandatory role where through the intermediary of laws and government regulations, the government can supervise, evaluate, and also re-check the results of CSR reports sent by companies. The second role is endorsement where transparency in reporting is carried out with positive efforts. Then the third is the role of partnering where the government takes part in cooperation with multi-stakeholders by promoting initiatives for partnerships. And the last is facilitating where the government becomes a facilitator by providing guidelines in the implementation of CSR programs as well as a means of delivering information to companies [18].

As a support effort and also to ensure the achievement of the objectives of implementing CSR and creating an effective balance between development and the environment, the role of government is needed with good governance [19]. Good Governance is defined as a benchmark in the process and structure of a good connection between socio-economic and political. In the implementation of good governance, there are three focuses that are related to one another, namely the fields of administration, politics, and economics. In the administrative field, it includes the implementation of policy systems at the regional level and also at the national level. In the political field, it includes the entire process of making decisions in making regulations and policies. Meanwhile, in the economic field, it includes all decision-making processes that affect economic factors as well as economic activity itself, such as poverty, quality of life, and justice [20].

A policy will be said to be successful in implementing CSR programs if it fulfills four success requirements, namely:

1) Communication: how companies and governments communicate with each other in implementing CSR.

2) Bureaucratic structures (Beureucratic structures): bureaucratic structures greatly affect CSR programs because in the implementation of CSR there must be compatibility between bureaucratic institutions and companies that run CSR programs.

3) Resources (Resources): everything related to supporting resources, especially human resources. Because it is related to proficiency in implementing public policies to be carried out effectively.

4) Disposition: in implementing the CSR program, skills alone are not enough, it requires loyalty and commitment from the role of the company that implements it in accordance with public policy. 
Some ASEAN countries such as Thailand and the Philippines refer to the selfawareness of each company party, the government has little role and authority in this regard. In implementing CSR programs, the government only has a role in advocating and coordinating, cannot regulate the course of CSR and also does not make official regulations regarding the CSR program itself.

\subsection{Government of Indonesia and implementation of CSR programs}

From the previous explanation, Indonesia is one of the countries that oblige to carry out CSR for companies that in carrying out and or carrying out their business related to natural resources. Laws and government regulations are made by the government to carry out and implement CSR programs which are written in Law No. 40/2007 which discusses all forms of Limited Liability Companies (UUPT) and Government Regulation No. 47/2012 regarding all forms of Social and Environmental Responsibility (TJSL) Limited Liability Company. Article 74 of the Company Law, paragraph 1 explains that CSR or CSR is an obligation for companies whose business activities are carried out or related to natural resources and have an impact on nature. Meanwhile, in paragraph 3, it is stated that the sanctions for companies that do not carry out CSR with sanctions that will be given in accordance with the decisions of applicable and related laws and regulations.

Social and environmental responsibility is a commitment from a company to take an active role in sustainable economic development to improve the quality of life, both the quality of life for the community, the environment, relevant stakeholders, and also the company itself. In Article 2 of Government Regulation Number 47 of 2012 concerning Social and Environmental Responsibility of Limited Liability Companies (PP 47/2012) which states that every limited liability company as a legal subject has social and environmental responsibilities. However, in the government regulation, it should be noted that those who are obliged to carry out social and environmental responsibilities are companies related to natural resources in their business activities.

With the policies and regulations made by the government, the implementation of CSR is like a very burdensome obligation. However, this obligation is not a burdensome burden. All business actors cooperate with the government and regulations that are obliged to implement CSR are companies that utilize natural resources in running their business.

Companies that carry out their business activities in the field of natural resources are companies that have activities in the management and utilization of natural resources, while companies related to natural resources are companies in which the company does not manage or utilize natural resources. What they do has an impact on the function of natural resources, including in the preservation of the environment. Obligations to companies that carry out their business activities in the field and related to natural resources have differences in accordance with those contained in the Constitutional Court Decision Number 53/PUU-VI/2008 which is also in the activities of managing natural resources of a company related to article 33 paragraph ( 3 ) the 1945 Constitution so that the state has the right to give different regulations to the company. Although there are already laws and other regulations that already regulate social and environmental responsibilities, in practice some regions have regulated the minimum amount of budget for carrying out social and environmental responsibilities in local regulations (Perda) [21].

Regarding the uncertainty of whether CSR is something that must be carried out by the government or not, the answer depends on where the company is located. If the company is established in Thailand and the Philippines, it is certainly not mandatory to carry out CSR programs. However, if the company is established in Indonesia, it becomes an obligation for the company to carry out CSR programs for companies that run and or are engaged in the field of natural resources. Because here the role of the Indonesian government as a 
regulator is a form of concern for the community and the environment. If the company wants to carry out CSR voluntarily, the company can run it directly. However, it is more ethical if the company first communicates about their program to the government because later the CSR program must have a responsibility. Responsibility for CSR is carried out in the form of CSR activity reports which are updated annually through the respective company web sites.

\subsection{Multinational Enterprises and Sustainable Development in Indonesia}

A company will not be separated from the existence of social responsibility or what is commonly referred to as corporate social responsibility (CSR). Where those who have the obligation to run it are not only large companies, but all types of companies, both large and small companies, multinational companies and domestic companies must continue to carry out their social responsibilities. Apart from being a form of their concern for the community and the environment, it is also a form of the company's contribution in realizing the achievement of sustainable development goals in Indonesia.

\subsubsection{Multinational Corporation}

Multinational Companies or Multinational Corporations (MNC), hereinafter referred to as MNCs, are the main actors in international business. MNC has an extraordinary existence in developing countries including Indonesia, MNC has dominance in the availability of goods for human needs ranging from primary needs to secondary and even tertiary needs. MNCs have a very large influence on local economic growth and also have a very important role in globalization and international relations. Likewise in the realm of political economy, MNCs also play the role of subjects as actors and also as objects of targets for actors in the realm of political economy [22].

MNC can be defined as a company engaged in direct investment, namely in foreign direct investment (FDI), within certain limits, and controls the added value of activities in a country [6]. In general, FDI activities are carried out in subsidiaries which can be in the form of wholly owned subsidiaries (subsidiaries where MNC has a majority in share capital ownership), minority equity investments (companies where $\mathrm{MNC}$ is a minority shareholder) (Alfaro, 2003). Multinational companies take various forms, ranging from small companies that have invested abroad or in large groups that also manage branches of companies in a number of destination countries or host countries [23].

According to data from the United Nations Conference on Trade and Development (UNCTD) in 2011, there are about 82,000 multinational companies in the world where these companies have 810,000 branches or subsidiaries located in various countries in various parts of the world. Among the top 500 multinational companies, there are 133 head offices located in the United States, 68 in Japan, 61 in China, 35 in France, 34 in Germany, and 30 in the UK [24]. In this era, many multinational companies come from developing countries. They prove to the world that developing countries are also able to compete in the international trade arena.

Multinational companies have characteristics including having various branches in other countries, having strategies and visions that are used in global goods production activities so that these companies can create and produce products that can be used by all countries in the world. Usually multinational companies are more likely to choose manufacturing as their business activity.

Multinational companies also provide benefits for a country that is the host country for the multinational company. Some of the benefits obtained by the host country are the increase in the host country's economy with foreign exchange and taxes from these 
multinational companies. Because usually the profits of multinational companies will be taxed by the government and this tax will increase income for the host country. Reduced unemployment in the host country. Get technology transfer from home country. Where multinational companies bring super-sophisticated technology from their home countries as home countries. The super-sophisticated technology is then applied in the host country. Increasing the national reputation because of the presence of a multinational company in the host country or host country will give a good image among the industry of other multinational companies. When a country's reputation is good and tends to increase, other foreign investors will be interested in investing in that country.

\subsubsection{Unilever Indonesia}

Unilever has been a friend of the Indonesian people by accompanying them on a daily basis for more than 85 years. For more than 85 years of being established and being a friend of the Indonesian people, Unilever's mission has never changed, namely campaigning for sustainable living by paying attention to positive benefits to society and the environment in order to achieve a sustainable society. Unilever Indonesia was first established on December 5, 1933 under the name "Lever's Zeepfabrieken NV" located in the Angke area, North Jakarta based on deed no. 23 of Mr. AH van Ophuijsen, notary in Batavia. The deed was approved by General Geoual van Nederlandsch-Indie based on letter No. 14 on December 16, 1933, registered at the Raad van Justitie in Batavia with No. 302 on 22 December 1933 and published in the Javasche Courant on 9 January 1934. Supplement No. $3[3]$.

With Unilever's presence in Indonesia, Unilever wants to provide benefits for all parties, including the community, the environment, and the government. Unilever wants to be a solution to all the problems and challenges that exist in Indonesia such as poverty, waste management, sanitation, nutrition, sustainable resources, climate change, and also health problems. Unilever always gives its best effort to create a better future every day through its campaigns and products. In conducting its business, Unilever has developed new ways that will allow Unilever to continue to grow while reducing its impact on the environment and increasing its positive impact on society and the environment.

Unilever Indonesia has a sustainability program that is carried out with the principles and pillars of the Unilever Sustainable Living Plan (USLP). The pillars and principles are improving people's livelihoods, improving welfare and health, and reducing impacts on the environment. The program is carried out as a reflection of a company that has social responsibility. There are 44 brands currently owned by Unilever where these brands are produced in nine factories located in the industrial area of Jababeka- Cikarang, RungkutSurabaya, and has a head office in Tangerang.

Of the nine factories owned and the products produced by these factories have received certification from the Indonesian Ulema Council (MUI) as halal goods for use and consumption by the public. Unilever has 1,000 stock keeping units (SKUs) which are marketed through more than 800 independent distributor networks that reach hundreds of thousands of stores throughout Indonesia [3].

\subsubsection{Sustainable Development Goals in Indonesia}

So far, both developed and developing countries must have faced problems. However, the problems faced by developing countries are more complicated and more numerous. Starting from poverty, hunger, education, and others. Seeing these problems faced by developing countries, the United Nations (UN) took the initiative to eliminate the problems faced by developing countries by formulating the SDGs. 
In 2015, precisely in September, the United Nations (UN) agreed on the SDGs as one of the UN agenda at the UN general assembly in New York, USA [25]. This agreement is the starting point for the creation of a new history in global development. 193 leaders of countries and governments in the world attended the agreement on the new universal development agenda which was contained in a document entitled Transforming Our World: the 2030 Agenda for Sustainable Development which provided 17 goals and 169 targets applicable in 2016 to 2030 . The document was then given a name and known as the Sustainable Development Goals or in short known as the SDGs [26].

One of the goals of the SDGs is good health and well-being, to be precise, the 3rd goal of the SDGs. The United Nations says significant steps have been taken to improve lives and reduce maternal and child mortality. Significant improvements have also been made in improving sanitation and clean water, reducing the spread of HIV/AIDS, malaria, polio and tuberculosis. However, more efforts are needed to deal with various diseases and health problems that arise continuously. There are 13 targets and 28 indicators for the 3rd SDGs that have been set by the United Nations and some of them are:

1. Achieving Universal Health

Ensure all forms of health including financial risk protection, access to medicines and vaccines as well as safe, effective, quality and affordable health services for all. The indicators for achieving this goal are the coverage of health services and household expenditure on health, with the target by 2030 achieving health coverage including financial risks, access to medicines and vaccines as well as safe, effective, quality and affordable health services for all [27].

2. Reducing deaths and illnesses caused by pollution and harmful chemicals

Indicators of achieving this goal are reduced death rates due to air pollution, reduced mortality rates caused by unhygienic water and sanitation, and reduced mortality due to hazardous chemicals and soil pollution [25].

3. Increase health financing and support health workers

Increase health financing and recruitment, development, training, and retention of health workers in developing countries as well as in least developed countries with indicators of adequate density and distribution of health workers. Density of health workers is the number of health workers per 1,000 people as measured by the density of doctors, nurses and midwives, surgeons, dentists and pharmacy personnel [25].

Of the three indicators mentioned above, the last indicator, namely increasing health financing and supporting health workers is an indicator in this study. Thus, the SDGs are expected to be realized and implemented by all parties who take part in the development process for 2016 - 2030. At the same time Indonesia is also predicted to experience a demographic bonus [28]. This is a motivation for Indonesia to create a sustainable society with the help of residents of productive age. In addition, the role of all parties, including the government, the community and also the private sector, such as companies, both national and multinational companies, is very important in realizing a better Indonesia.

\subsection{Unilever's Role in Achieving Sustainable Development Goals 2030 in Indonesia}

Realizing a sustainable country is the task of the government, but to make this happen the government needs assistance from stakeholders which includes companies in Indonesia. As a leading company in Indonesia, Unilever has an active role in helping to achieve the goals 
of SDGs 3 regarding health. Large or in any business activity. Unilever also wants to show that good things can be created by the actions of business people.

In 2010, Unilever introduced the Unilever Sustainable Living Plan (USLP). While business people think that business and sustainability are two different things, Unilever thinks that they are one thing. With the USLP, Unilever examines every aspect and builds a business that will help sustain life globally. By running a responsible business, Unilever believes that this is the best way to do business. USLP continues to strive to have a positive impact on our planet, consumers and businesses as a whole.

Unilever Indonesia within the local reach is making a real effort to implement the USLP in the Unilever business chain as a whole, with a focus on three main objectives of improving people's welfare and improving community health, improving people's livelihoods, and reducing negative impacts on the environment. By focusing on these three main goals. Unilever believes it can create a better world.

As the main means of implementing the USLP, especially within the community, Unilever established a foundation called the Unilever Indonesia Foundation (YUI). Formed in 2000 to be exact on November 27. YUI was formed not without a purpose and without a mission, YUI's mission is to explore, discover, and empower the potential of the community, as a bridge to establish partnerships, unite strengths with all partners, and provide added value to the community.

Unilever-owned brands such as Lifebuoy and Vixal are doing their best to achieve health goals by reducing the incidence of preventable diseases such as diarrhea and pneumonia by adopting a healthy and clean lifestyle and behavior. Since the inception of the USLP, Unilever has helped more than 600 million people around the world improve their health and hygiene. As for Indonesia itself, Unilever has reached around 90 million people to implement healthy and clean living habits. In the period up to 2030, Unilever is committed to halving the environmental impact of the production and use of Unilever products.

Unilever's products such as Pepsodent, Wipol, Vixal, Lifebuoy, and also Vaseline have a good aim of helping to improve health and more importantly saving one's life. Many things have been done as Unilever's efforts in helping a healthy and clean community, ranging from healthy school programs to improving nutrition for the nation's children. Unilever's efforts to achieve the SDGs with the aim of good health and well-being by achieving health financing indicators and providing health workers with various contributions. I group these contributions into two, namely:

\subsubsection{Unilever's contribution in helping to increase health financing}

As a contribution to helping increase health financing in Indonesia, Unilever has many programs for the community. The increase in health financing is not only in the form of materials provided to the community but also in the form of providing medical equipment, health products, as well as health education and health education programs that require costs in their implementation. There are various programs including the healthy school program, World Handwashing Day, National Dental Health Month, World Dental and Oral Health Day, as well as Pepsodent Dental Care, Healthy Village Program, Empowered Healthy Market Program, Care for Surrounding Areas. Educating students about seven clean and healthy living behaviors. The education is carried out with the aim of reducing the risk of disease. In running the healthy school program, the Unilever Indonesia Foundation collaborates with the Ministry of Health and is also assisted by organizations such as NGOs or local communities to conduct training of trainers for teachers. In addition to the Healthy School program, there is also a Healthy Pesantren program which also aims to create a clean and healthy pesantren environment. 
World Handwashing Day is also a program from Unilever, more precisely from Lifebuoy as one of Unilever's brands. This World Handwashing Day is held in several schools in Indonesia every year. There are three pillars in the implementation of this program, namely the school pillar, the Posyandu pillar in collaboration with PKK, and the hospital pillar in collaboration with PERSI. Each pillar has a different target. The school pillar makes students their target, the posyandu pillar to reach the household environment, and the hospital pillar to provide education to health workers.

In addition to the above programs, Unilever has also set a target to inspire 100 million people in Indonesia, both in rural areas and in urban areas throughout the country, to take steps to improve the health and welfare of the Indonesian people. Unilever takes various forms of efforts to achieve the target of improving health in Indonesia with the Mothers in Posyandu program as a program supported by the Lifebuoy brand that focuses on education on clean and healthy living behavior at the smallest level, namely the family level for mothers who have children under five years old. In addition, this program also pays special attention to mothers who are having children for the first time with the aim of increasing the survival rate of newborns with good and correct practice of washing pliers with soap. By collaborating with activists from the PKK, namely the family welfare movement program that provides education about basic hygiene to more than 4 million mothers in Indonesia.

Unilever provides support in the development of a child-friendly public space called the Children's Home Integrated Public Space (RPTRA) in the Jakarta area. With the construction of these facilities, which are equipped with hall facilities for meetings and also the implementation of community activities. The development is supported by various private sectors as well as partners in various forms ranging from funding to soft skills training. Unilever, in collaboration with local partners, held a training of trainers for 100 mothers who had previously become activists and movers in the community. In this program, mothers are equipped with public speaking skills to campaign for a healthy and clean living culture to the community with a wider reach. In the training, the mothers were given training in the form of proper and proper hand washing with soap, brushing teeth in the morning and evening, using the toilet properly, eating a balanced menu, and consuming hygienic drinking water.

In addition to programs for urban areas, of course there is a program for rural areas called the Healthy Village Program. The program empowers rural areas to improve all aspects of health, from hygiene and good nutrition. Unilever Indonesia has collaborated with local partners to provide communities in 12 villages in Central and East Java with the skills and knowledge to be actively involved in improving community health, hygiene, and priority nutritional needs. The Healthy Village Program has also been coordinated with local community health centers, namely Puskesmas and Posyandu.

Then there is the Healthy Markets Empowered Program where the program focuses on mobilizing traders in traditional markets to strengthen their advantages and encourage business through fresh behavior, improving sanitation access, and creating a healthy and safe environment without losing the essence of traditional markets. By collaborating with several local partners, Unilever has provided facilities to more than 7000 traders in 10 traditional markets in Yogyakarta, East Java, DKI Jakarta, West Java, South Sulawesi, and also North Sumatra. Unilever enhances the program in coordination with the government. The YUI community by cooperating with local partners plays a role in intensive training using a participatory approach by actively and effectively involving market traders and encouraging open discussions on issues related to sanitation, environmental hygiene, and also cleanliness in the market. In addition, YUI also created the Perfect Community initiative to increase the Unilever brand market in traditional markets where this initiative has given tangible results for Unilever and for market residents. YUI 
has also launched the book Healthy Market Empowered Program as a form of dissemination to a wide audience.

The next program, namely the Care for Area Surrounding (CFAS) program, is a program developed to create and strengthen employee awareness about the importance of establishing relationships with the surrounding community. The program provides an opportunity for every employee to take part in every activity aimed at the community, such as providing education regarding clean and healthy living habits, creating a greener and cleaner environment.

In addition to the programs mentioned above, there is also the role of Unilever in increasing health financing and supporting health workers in the era of the COVID-19 pandemic. Since the beginning of the COVID-19 pandemic, various types of contributions have been made and will continue to contribute in this pandemic era. Various forms of contribution are sought, and one form of Unilever's contribution is to provide assistance worth IDR 200 billion given since the beginning of March 2020 both independently and in collaboration with partners. The support provided by Unilever is divided into three things, namely protecting the health of all employees, as a tangible form of the role that Unilever always responds to in meeting consumer dynamics, as well as providing real efforts to support the welfare and health of the community [29].

Unilever is also supported by Unilever's commitment to always provide its products for all groups of people in need. Because Unilever has guidelines for donating first before selling. By always voicing the spirit of Mri Sharing Roles since the beginning of the Covid19 pandemic, Unilever Indonesia with its brands has supported all efforts to maintain the welfare of the community and public health in a wide range by providing donations channeled through 102 referral hospitals throughout Indonesia, 29 community group partners and/or NGOs, 20 government institutions, and 39 Unilever partners [30].

In addition to support for the community in general, Unilever also provides medical personnel who take part and have an important role in handling COVID-19 in Indonesia. Several forms of support were provided, namely initiating "meals for meals" in which Unilever and employees cooperated with each other by donating 52,000 food packages which were distributed to medical personnel in stages. Donated 60,000 N95 masks for 8 referral hospitals under PERSI as well as through the Bekasi Regency Health Office and also Tangerang Regency to provide health facilities from Unilever for medical personnel in the area. By collaborating with the Indonesian Mosque Council (DMI) donations in the form of health and hygiene tools and products were given to 100,000 mosques throughout Indonesia. With the intermediary of the National Disaster Management Agency (BNPB) Unilever donated 40,000 PCR test kits to medical personnel on duty in laboratories, hospitals and health facilities in Indonesia [31].

In addition to medical equipment and necessities, Unilever also donated from their products such as hand sanitizers, soaps, hygienic care products for homes, food and beverage products, as well as food packages for medical personnel worth 10 billion donated through the Chamber of Commerce and Industry (Kadin) to DKI Jakarta provincial government. In addition to Jakarta, Unilever also donated their products, namely 10,000 Lifebuoy hand sanitizer products, 2,880 units of PCR test kits, 250 units of portable sinks, 3000 units of KN95 masks, as well as providing PHBS educational materials to the Surabaya city government. Donations in the form of 15,000 Vaseline petroleum jelly products were given to health workers and Unilever collaborated with the Indonesian Red Cross (PMI) to distribute Unilever products ranging from health products to food and beverage products to 249,952 families (KK) in 3 provinces and 13 districts or cities in Indonesia [32].

Currently the vaccine for COVID-19 is being intensively distributed to various regions in Indonesia. Because the government has not been able to do it on its own, the 
Government has experienced problems in distributing vaccines for COVID-19 when the distribution of 1.2 million doses of Sinovac vaccine to regions in Indonesia. These obstacles were encountered in eight provinces where the obstacles were caused by the lack and inadequate cold storage capacity for the COVID-19 vaccination program because the COVID-19 vaccine made by Sinovac had to be placed in storage at a temperature of 208 degrees Celsius, and the government felt that this was the case. It is difficult because to prepare for storage with a cold temperature system for 20 thousand health centers throughout Indonesia is more difficult than checking and controlling the existing vaccine stock [33].

Therefore, the government will cooperate with the private sector to distribute the COVID-19 vaccine cold chain. PT Unilever Indonesia Tbk is one of the companies that are partnered with the government to synergize with the government for the distribution of the vaccine. Unilever has expertise in the supply chain according to needs, with one of the businesses owned by Unilever, namely the ice cream business that uses freezing in its distribution, so Unilever certainly has knowledge and experience in all aspects related to storage with refrigeration equipment to the distribution destination. Since the beginning of the pandemic, Unilever has proven its commitment to helping the community by making various donations by providing tens of thousands of test kits, tools and products for adequate sanitation for the community, as well as food packages and PPE for medical personnel who are at the forefront of tackling COVID -19. And at this time Unilever also continues to be committed to supporting and synergizing with the government in facing the challenges that occur in the era of the COVID-19 pandemic which is currently a big challenge for the community and also for the government. With the commitment that Unilever has, it is hoped that it can inspire various groups to care and be responsive to this problem so that Indonesia can rise from adversity and become a stronger country [31].

\subsubsection{Unilever's contribution by supporting the provision of health workers in Indonesia}

In supporting the provision of health workers in Indonesia, Unilever demonstrates this with the National Dental Health Month program, World Dental and Oral Health Day, and Pepsodent Dental Care, a program from Pepsodent as one of Unilever's leading brands. The National Dental Health Month is carried out by collaborating with the Indonesian Dentist Association and the Association of Indonesian Dentistry Faculties, maximizing dental and oral health services ranging from education to treatment and also free dental check-ups for the people of Indonesia. Slightly different from World Dental and Oral Health Day where Pepsodent collaborates with FDI World Dental federation and also PDGI in assisting the government in realizing a caries-free Indonesia in 2030. The partnership has been running for approximately 25 years where it has been proven that the level of frequency in brushing teeth has increased to 25\% worldwide [30]. In 2013 Pepsodent established Pepsodent Dental Expert Center as the largest dental edutainment center located in Gandaria City mall, Jakarta. There are very sophisticated dental examination equipment, such as a caries detector. Apart from being a place for consultation and dental treatment, Pepsodent Dental Expert Center also opens a program for school visits where students can learn firsthand how to take good care of their teeth from experts and also from animated cartoons that are shown in the auditorium. With this program Unilever provides health workers, especially doctors and dentist assistants by recruiting young doctors and also working with PDGI to provide dentists for the Indonesian people [30].

From the description above, Unilever seeks to assist Indonesia in achieving the SDGs in Indonesia, especially the number three goal, namely good health and well-being by increasing health financing which is meant not only in the form of materials provided to the 
community but also in the form of providing health equipment., health products, as well as health education and health education programs that require costs in their implementation and support the availability of health workers, especially dentists and dental assistants in Indonesia, where the program has met the achievement indicators, namely increasing health financing and supporting health workers' health.

\section{Conclusions and Recommendations}

Social responsibility or Corporate Social Responsibility and the company are an inseparable unit. Likewise with the implementation of CSR which cannot be separated from the contribution in realizing the achievement of the SDGs in Indonesia. Both local companies and multinational companies have a responsibility to carry out CSR in every area where the company is located. Every company has a different way of contributing and so does Unilever.

In the implementation of the CSR program, it does not only involve the company and the community, but there are other stakeholders such as the government. In terms of corporate social responsibility to society and the environment, the government here has two roles. The first role is the government as an institution that requires CSR for all companies without exception and the second is that the government has no authority over CSR programs carried out by companies. The government's role in implementing CSR programs depends on the country where the company is located. However, for companies that are established in Indonesia, it is an obligation to carry out CSR activities for companies that in carrying out and or in their business processes utilize natural resources.

In the explanation of the previous chapter, there are examples of companies that carry out CSR to achieve a sustainable society, namely Unilever as a multinational company and also included in the FMCG company. Several efforts have been made by Unilever to assist Indonesia in achieving the SDGs in Indonesia, especially goal number 3, namely good health and well-being with achievement indicators, namely increasing health financing and supporting health workers in Indonesia.

With a program owned by Unilever, namely the Unilever Living Plan (ULP), which is an effort by Unilever to create a sustainable society with three main objectives: improving community welfare and improving community health, improving people's livelihoods, and reducing negative impacts on the environment. Efforts in terms of health financing are implemented through health programs organized by Unilever such as the healthy school program, world hand washing day, national dental health month, healthy village program, healthy market program, maternal and child health program, and care for health programs surrounding area. In addition to this in achieving indicators of increasing health financing, Unilever is committed to continuing to maintain public health with the products they have.

Unilever has made significant improvements in health financing indicators in achieving the indicators during the Covid-19 pandemic. Unilever provides assistance worth IDR 200 billion that has been given since the beginning of March 2020 both independently and in collaboration with partners distributed to 102 referral hospitals throughout Indonesia, 29 community group partners and/or NGOs, 20 government institutions, and 39 Unilever partners. Unilever donated tens of thousands of test kits, tools and products for adequate sanitation for the community, as well as food packages and PPE for medical personnel who are at the forefront of tackling COVID-19.

Unilever also supports the provision of health workers, especially dental health workers, Unilever and its brand, Pepsodent, always synergize with dentists in Indonesia to support the dental and oral health of children and the Indonesian people. 
From the previous description, it has indirectly explained that Unilever has assisted Indonesia in achieving the 3rd SDGs goal by achieving achievement indicators in the form of achievement, namely increasing health financing and supporting health workers in Indonesia. The explanation above also shows that Unilever as a CSR actor applies ethical theory in its implementation. Where the activities and efforts carried out by Unilever are focused on the right thing to achieve a better society based on the company's responsibility to the parties concerned. Unilever also highly respects human rights, the environment and the rights of employees.

Indirectly, the author's hypothesis, namely how Unilever helps achieve the Sustainable Development Goals in Indonesia and contributes to the achievement of the 3rd SDGs goal, namely good health and well-being through increasing health financing and supporting health workers, has been answered in the description in the previous chapter, namely by increasing health financing. What is meant is not only in the form of materials provided to the community but also in the form of providing medical devices, health products, as well as health education and health education programs that require costs in their implementation and support the availability of health workers, especially dentists and dental assistants in Indonesia. Hopefully, this research can be used as a reference for future research.

\section{References}

1. M. Mas'oed, Perusahaan Multinasional dalam Ekonomi Politik Internasional. Yogyakarta: Universitas Gajah Mada, (1997)

2. R. Gilpin, Understanding the international economic order, (2001)

3. Unilever Indonesia, Tentang Kami. Retrieved from Unilever Indonesia: https://www.unilever.co.id/about/who-we-are/introduction-to-unilever/, (2021)

4. C. Sundari, Mengenal "Fast Moving Consumer Goods". Retrieved from Kompasiana: https://www.kompasiana.com/cindysundari/54f70194a33311d6218b4583/mengenalfast- moving-consumer-goods, (2014)

5. Unilever Indonesia. Our History. Retrieved from Unilever Indonesia: https://www.unilever.co.id/about/who-we-are/our-history/, (2021)

6. J. H. Dunning, S. M. Lundan. Multinational enterprises and the global economy. Edward Elgar Publishing, (2008)

7. L. Aqiela, S. T. Raharjo, R. Resnawaty, Implementasi Program Corporate Social Responsibility (CSR) El-Corps, Share: Social Work Journal 8, No. 2, 211-218 (2018)

8. J. Frynas, Beyond Corporate Social Responsibility, Oil Multinationals and Social Challenges, Cambridge: Cambridge University Press, (2009)

9. M. B. Santoso, S. T. Raharjo. Corporate social responsibility (CSR) dari sudut pandang perusahaan, Share: Social Work Journal 4, No. 1, (2014)

10. Y. Wibisono, Membedah Konsep dan Aplikasi Corporate Social Responsibility, Gresik: Fasco Publishing, (2007)

11. F. A. Setiawan, F. P. Hapsari, Securitizing e-Waste: Framing Environmental Issue as a Threat to Human Security. Jurnal Hubungan Internasional, 6, No. 2, 210-220, (2018)

12. R. Barus, Pengaruh Implementasi Corporate Social Responsibility Terhadap Profitabilitas Perusahaan Perkebunan. Jurnal USU, (2013) 
13. B. Z. Rahmat, Corporate Social Responsibility dalam Perspektif Etika Bisnis Islam. Jurnal Ekonomi dan Keuangan Syariah 1, No. 1, 98-113, (2017)

14. Y. M. Yani, V. Robertua, RSPO, ISPO and Global Environmental Governance: An English School Perspective. Jurnal Hubungan Internasional 6, No. 1, 99-112, (2017)

15. F. Al-Fadhat, S. S. Nadita, Questioning Sustainability: Economic Expansion and Contradictions behind India's Eco-Friendly Textile Policy, Asian Affairs, 52, (2), 396411, (2021)

16. R. Steurer, The Role of Government in Corporate Social Responsibility : Characterising Public Policies on CSR in Europe. LLC: Spring Science+Business Media, (2009)

17. T. W. Fox, Public Sector Roles in Strengthening Corporate Social Responsibility: A baseline Study. The World Bank, (2002)

18. I. Mariane, Peran Pemerintah dalam Pemberdayaan Perempuan melalui Corporate Social Responsibility (CSR). Jurnal Ilmu Administrasi 11, No. 1, (2020)

19. C. Rees, Conflict Resolution and Prevention through CSR. Jakarta: Pricewaterhouse Coopers. (2006)

20. A. Kuncoro, Corruption and Business Uncertainty in Indonesia. Asean Economic Bulletin. (2006)

21. E. Permatasari, Klinik Hukum. Retrieved from Hukum Online Web Site: https://www.hukumonline.com/klinik/detail/ulasan/lt5f979e0658d4a/berapa-anggarancsr-yang-wajib-dikeluarkan-perusahaan/, (2006)

22. P. Anoraga, Perusahaan Multinasional dan Penanaman Modal Asing. Jakarta: Pustaka Jaya, (1994)

23. U. Mayrhofer, Management of Multinational Companies: A French Perspective. Basingstoke: Palgrave Macmillan. (2012)

24. Fortune Global Magazine. Ranking of the world's 500 largest companies. New York: Fortune Magazine (2011)

25. T. Theresia, Analisis Penerapan Suistanable Development Goals (SDGs) pada Beberapa Anggota Indonesia Global Compact Network (IGCN). National conference of creative industry, 941-951, (2018)

26. W. Wahyuningsih, Millenium Develompent Goals (MDGs) dan Sustainable Development Goals (SDGs) Dalam Kesejahteraan Sosial. Bisma Jurnal Bisnis dan Manajemen 11, 390- 399, (2017)

27. United Nations, Sustainable Development Goals. Retrieved from SDG Tracker: https://sdg-tracker.org/good-health, (2020)

28. M. A. Umar, Bonus demografi sebagai peluang dan tantangan pengelolaan sumber daya alam di era otonomi daerah, Genta Mulia: Jurnal Ilmiah Pendidikan 8, No. 2, (2018)

29. Unilever Indonesia. Prakarsa dibidang peningkatan kehidupan. Retrieved from Unilever Web Site: https://www.unilever.co.id/sustainable-living/prakarsakeberlanjutan/prakarsa- di-bidang-peningkatan-penghidupan/, (2020)

30. Unilever Indonesia. Unilever Ambil Peran dalam Melindungi Masyarakat Indonesia dari Pandemi Covid-19. Retrieved from Unilever web site: 
https://www.unilever.co.id/news/press-releases/2020/unilever-ambil-peran-dalammelindungi-masyarakat-indonesia-dari-pandemi-covid-19, (2020)

31. Unilever Indonesia. Prakarsa di Bidang Lingkungan. Retrieved from Unilever web site: https://www.unilever.co.id/sustainable-living/prakarsa-keberlanjutan/prakarsa-dibidang- lingkungan/, (2020)

32. Unilever Indonesia. Prakarsa di Bidang Kesehatan. Retrieved from Unilever web site: https://www.unilever.co.id/sustainable-living/prakarsa-keberlanjutan/prakarsa-dibidang- kesehatan/, (2020)

33. K. Safitri, Unilever Siap Bantu Distribusi Vaksin Covid-19. Retrieved from https://money.kompas.com/read/2021/01/19/130000026/unilever-siap-bantudistribusi- vaksin-covid-19, (2020) 